Yerbilimleri, 2019, 40 (2), 168-189, DOI:10.17824/yerbilimleri.508154

Hacettepe Üniversitesi Yerbilimleri Uygulama ve Araştırma Merkezi Bülteni

Bulletin of the Earth Sciences Application and Research Centre of Hacettepe University

\title{
Yansıma Seyahat Zamanı Tomografisi: İzmir Körfezi için Örnek Bir 2B Çalışma
}

Reflection Traveltime Tomography: A 2D case study from Gulf of Izmir (Turkey)

\author{
ZEHRA ALTAN ${ }^{1 *}$, NESLIHAN OCAKOĞLU ${ }^{1}$, GUALTIERO BÖHM ${ }^{2}$ \\ ${ }^{1}$ İstanbul Teknik Üniversitesi, Maden Fakültesi, Jeofizik Mühendisliği Bölümü, 34469 İstanbul, Türkiye \\ ${ }^{2}$ Istituto Nazionale di Oceanografia e di Geofisica Sperimentale (OGS), 34010 Sgonico (TS), Italy \\ Geliş (received): 4 Ocak (January) 2019 Kabul (accepted) : 25 Temmuz (July) 2019
}

\section{Öz}

Bu çalışma kapsamında, İzmir Körfezi Foça açıklarında toplanan çok kanallı bir sismik yansıma profiline, yansıma seyahat zamanı tomografisi yöntemi uygulanarak sahanın hızderinlik modeli ilk kez ortaya çıkarılmıştır. Ham atış verileri, gürültülü izlerin ayıklanması, direk varışların kesilmesi, çentik filtreleme ve küresel genlik kazanımı gibi ön veri-işlem adımları uygulanarak iyileştirilmiştir. Önceki çalışmalarda rutin veri-işlem adımları kullanılarak elde edilen sismik göç kesitleri, bu çalışmada stratigrafik anlamda detaylı olarak yorumlanmış ve belirlenen ara yüzeyler, ön veri-işlem adımları uygulanmış atış kayıtları üzerinde işaretlenmiştir. Işın izleme ile hesaplanan seyahat zamanları, eşzamanlı yinelemeli yeniden yapılandırma (SIRT) yöntemiyle ters çözüm aşamasında kullanılarak lokal ara hızlar hesaplanmıştır. Her yinelemede elde edilen bu hızlar kullanılarak, ara yüzeylerin şekli ve derinliği ortaya çıkarılmıştır. Bu işlemler, seyahat zamanı rezidüelleri (işaretlenen ve hesaplanan seyahat zamanları arasındaki farklar) minimum olana kadar yinelenmiştir. Üretilen hız tomogramı, Foça açıklarında deniz tabanından itibaren yaklaşık olarak $1 \mathrm{~km}$ derinliğe kadar inen, beş farklı ara yüzey $(\mathrm{H} 1-\mathrm{H} 5)$ ile birbirinden ayrılmış dört farklı sismik ünitenin varığını ortaya koymuştur. Bu çökellerin $P$ dalgası ara hızları yaklaşık 1.5-2.6 km/s'ler arasında değişmektedir. En altta yer alan akustik temel (H5), batıdan doğuya

https://doi.org/10.17824/yerbilimleri.508154

\section{Zehra ALTAN zaltan@itu.edu.tr}

\footnotetext{
${ }^{1}$ İstanbul Teknik Üniversitesi, Maden Fakültesi, Jeofizik Müh. Bölümü, 34469 Istanbul, Türkiye ORCID 0000-0002-2355-4917

${ }^{1}$ Istanbul Teknik Üniversitesi, Maden Fakültesi, Jeofizik Müh. Bölümü, 34469 İstanbul, Türkiye ORCID 0000-0001-7641-2448

${ }^{2}$ Istituto Nazionale di Oceanografia e di Geofisica Sperimentale(OGS), 34010 Sgonico (TS), Italy ORCID 0000-0002-1234-392X
} 
doğru 800 metrelere kadar derinleşerek bir havza geometrisi oluşturmakta; söz konusu havza doğuda ise 440 metrelere kadar sığlaşarak bir sırt yapısı ortaya koymaktadır.

Havza içerisinde yer alan çökel paketleri havza geometrisi ile uyumlu olarak batıdan doğuya doğru derinleşerek kalınlaşmaktadır. Bu çalışma, yansıma seyahat zamanı tomografisi yönteminin, yeraltının derinlik ortamında stratigrafik yapısının detaylı olarak ortaya çıkarılması ve tabakaların ara hız modellerinin elde edilmesinde başarılı sonuçlar ürettiğini göstermiştir.

Anahtar Kelimeler: Sismik Tomografi, Seyahat zamanı ters çözümü, SIRT algoritması, Minimum Dispersiyon, İzmir Körfezi.

\section{ABSTRACT}

In this study, reflection traveltime tomography has been carried out on a multichannel seismic reflection data in the Izmir Gulf to obtain a velocity-depth model of the study area for the first time. The time-migrated seismic sections were interpreted stratigraphically before reflection traveltime tomography application. The raw shot gathers improved by performing preliminary data-processing steps such as noise elimination by editing, muting, notch filtering and spherical gain recovery. Migrated seismic sections produced by using conventional data processing scheme in previous studies were interpreted stratigraphically in detail. The interfaces defined on the migrated time sections were picked on the improved common shot gathers. Travel times calculated by ray tracing were used during travel time inversion adopting SIRT (Simultaneous Iterative Reconstruction Technique) algorithm to estimate the local interval velocities. These interval velocities estimated in each iteration were used for calculating the shape and depth of the interfaces in the study area. The velocity field is updated by minimizing the travel time residuals. Tomogram revealed that the velocity model of a sedimentary sequence of four seismic units with a thickness of about 1 $\mathrm{km}$ in the offshore Foça that are separated by five different interfaces (H1-H5). The interval velocities of these sedimentary sequences vary between $1.5-2.6 \mathrm{~km} / \mathrm{s}$. The acoustic basement (H5) constitutes a basin geometry that deepens to 800 meters from west to east and gets shallow up to 440 meters in the east forming a ridge. In addition to this, the sediment units in the basins deepen from west to east in accordance with the basin geometry. The investigation provided that the reflection traveltime tomography method is a good tool to obtain stratigraphical properties of layers in depth and to estimate an accurate interval velocity model of the seismic unit.

Keywords: Seismic tomography, Traveltime Inversion, SIRT algorithm, Minimum dispersion, Gulf of Izmir. 


\section{GíRiş}

Sismik yansıma yöntemi, yeraltının görüntüsünü en detaylı olarak ortaya koyan ve yerbilimlerinde yaygınca kullanılan bir yöntemdir. Bu yöntemin temel aşamalarından biri olan göç işlemi ile kaydedilen sismik veri yeraltındaki gerçek jeolojik konumuna taşınarak zaman ya da derinlik ortamında yorumlanmaya çalışılır. Sismik verilerin rutin veri işlemiyle elde edilen görüntüler genellikle zaman göçü kullanılarak çift yol seyahat zamanı ortamında üretilirler. Zaman göçü sonucu elde edilen çift yol seyahat zamanı kesitleri ortamın homojen olması (yanal yönde hız değişiminin olmaması) ve ara yüzeylerin, kaynak-alııının bulunduğu seviyeye paralel olduğu varsayımına dayanmaktadır. Ancak gerçekte yeraltında çok daha karmaşık jeolojik yapılar (tuz domları, kıvrımlar, faylar vb.) mevcuttur ve kaynakalıcı çalışma alanının topografyasından kaynaklı olarak her zaman ara yüzeylere paralel olmayabilir. İdealde istenen, elde edilen görüntülerin yapısal anlamda gerçeğe en yakın olması yani derinlik ortamında olmasıdır.

Derinlik dönüşümü, geleneksel veri-işlem yöntemleri ile elde edilen çift yol seyahat zamanı kesitlerinin derinlik ortamında incelenebilmesini sağlar. Derinlik dönüşümü çok genel bir terim olmakla birlikte, geçmişte geleneksel veri-işlem yöntemleri ile hızların bulunması, yığma öncesi zaman göçü uygulanmış kesitlerde sismik stratigrafik birimlerin yorumlanması, yorumlanan sismik stratigrafik birimleri birbirinden ayıran ara yüzeylere ait haritaların oluşturulması ve kuyu-kontrol atışlarından elde edilen hızlar kullanılarak derinlik dönüşümünün yapılması gibi bir dizi veri işlem adımı izlenerek gerçekleştirilmekteydi. Ayrıca kuyu-kontrol atışlarıyla elde edilen hız bilgisi kısıtlı ve her zaman güvenilir olmayabiliyordu. Gerçekleştirilecek olan derinlik dönüşümü ancak kullanılan hız modeli kadar iyi olabilir (Kessler vd., 2017). Günümüzde ise sayısal yeniden yapılandırma tekniği (ART-Algebraic Reconstruction Technique), eş zamanlı yinelemeli yeniden yapılandırma tekniği (SIRT-Simultaneous Iterative Reconstruction Technique) ve sınırlandırılmış hız ile ters çözüm (CVI-Constrained Velocity Inversion) gibi geleneksel olmayan yöntemler kullanılarak doğruluğu yüksek hız modelleri elde etmek mümkün hale gelmiştir.

Sismik hız bilgisi yeraltı stratigrafisinin anlaşımasında önemli bir rol oynar. Yüksek hızlar yeraltında volkanik kayaçlar, tuz domları vb. gibi sert kayaçların varlığına işaret ederken nispeten daha düşük hızlar sedimanter ortamların göstergesidir (Bourbié vd. 1987). Sedimanter havzalarda ortaya konan göreceli düşük hızlar ise ekonomik yönden öneme 
sahip hidrokarbon içeren ortamlara işaret edebilir. En doğru ve çözünürlüğü en yüksek hız bilgisi doğrudan kuyu ölçümleriyle elde edilebilir. Ancak kuyu ölçümleri oldukça maliyetli yöntemlerdir. Yeraltının gerçek hızlarına ulaşmak için sahada önceden açılmış kuyular ve bu kuyularda ölçülmüş hız bilgileri yok ise, sismik yansıma verilerinden yola çıkarak gerçekleştirilen sismik tomografi yöntemi daha az maliyet ile hız bilgisini verebilmektedir. Bu açıdan bakıldığında tomografi yöntemi ile geleneksel sismik yöntemlerden farklı olarak yinelemeli çözüm yaklaşımı ile yeraltının 2B ve/veya 3B tabakalı yapısına ait sismik ara hızlarına ve bu tabakaları birbirinden ayıran ara yüzeylerin derinliklerine ulaşmakta oldukça başarılı sonuçlar elde edilebilmektedir (Vesnaver, 1996; Vesnaver vd., 2000; Böhm vd., 2006; Böhm vd., 2009; Boehm vd., 2010; Rossi vd., 2011).

Çalışma alanı olarak seçilen İzmir Körfezi'nde (Şekil 1) daha önce yapılan çok kanallı sismik yansıma çalışmaları, körfezin havza-sırt geometrisini oluşturan akustik temel yapısını ve havza çökellerini yaklaşık 2.5 saniye derinliklere kadar ortaya koymuştur. Bu çalışmalar körfezin aktif tektoniğinden sorumlu pek çok doğrultu atımlı fayın varlığına da işaret etmiştir (Ocakoğlu, 2004; Ocakoğlu vd., 2005; Altan ve Ocakoğlu, 2016). Altan ve Ocakoğlu (2016), İzmir Körfezi iç kesimlerine doğru olası gaz içeren sığ sedimanların varlığını ortaya koymuştur. Körfezin devamında yer alan Batı Anadolu grabenlerinde ise yer yer hidrokarbon içeren havzaların varlığı önceki çalışmalar ile tespit edilmiştir (Çiftçi vd., 2004; Gürgey vd., 2007). Bölgedeki bu hidrokarbon arama faaliyetleri kapsamında Türkiye Petrolleri Anonim Ortaklığı (TPAO) tarafından 1987 yılında Foça açıklarında Foça-1 kuyusu açılmıştır. Fakat açılan kuyuda herhangi bir hidrokarbon bulgusuna rastlanmamıştır. Tüm bu çalışmalar göz önünde bulundurulduğunda, Batı Anadolu horst-graben yapısının İzmir Körfezi içerisindeki uzanımının ve geometrisinin derinlik ortamında araştırılması, havzaları dolduran çökel istifin stratigrafik anlamda detaylı incelenmesi ve bu istifi oluşturan her bir birimin $P$ dalgası ara hız dağılımları ile kalınlıklarının ortaya çıkarılması büyük önem taşımaktadır.

Bu çalışmada, önceki araştırmalar ile (Ocakoğlu, 2004) İzmir Körfezi'nde toplanmış olan bir grup çok kanallı sismik yansıma verisinden seçilen sismik yansıma hattına, seyahat zaman tomografi yöntemi uygulanarak yeraltının 2B hız-derinlik modeli detaylı olarak ortaya çıkarılmıştır. 


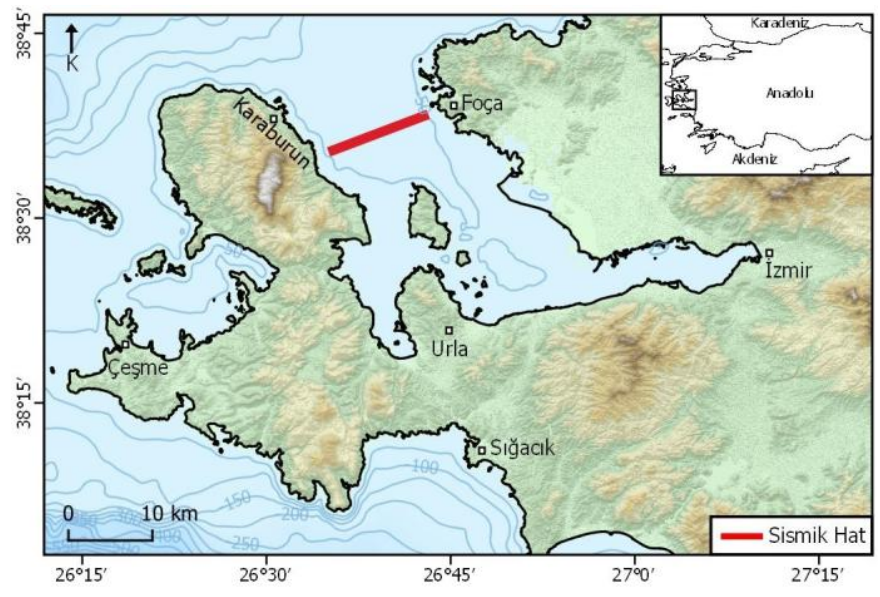

Şekil 1. Çalışma alanı lokasyon haritası (Batimetri verisi GEBCO, topografya verisi ise NASAEarthdata veritabanından alınarak yeniden üretilmiştir).

Figure 1. Study area and the location of the seismic profile (The bathymetry is reproduced from GEBCO database and the topography is reproduced from NASA-Earthdata database).

\section{KULLANILAN VERILER}

Seyahat zamanı tomografi yöntemi uygulamasında kullanılan çok kanallı sismik yansıma verisi, MTA kurumu tarafından ITU-TUBITAK-MTA ortaklığında 2000 yılında yürütülen bir araştırma projesi kapsamında, İzmir Körfezi Foça açıklarında toplanmıştır (Şekil 1) (Ocakoğlu vd., 2005). Veri toplama parametreleri; 48 kanallı alıcı, 2 msn örnekleme aralığı, toplam 3 saniye kayıt uzunluğu, $25 \mathrm{~m}$ atış aralığı, 12.5 metre alıcı aralığı, $10 \mathrm{~m}$ alıcı kablo derinliği, 5 metre kaynak derinliği, 50 m minimum ofset ve 838 metre maksimum ofset şeklindedir.

\section{YÖNTEM}

Tomografi, kelime anlamı olarak dilim anlamına gelen "topos" ile çizmek anlamına gelen "graphos" kelimelerinin birleşiminden oluşmuştur ve "kesmek/dilimlemek" anlamlarına gelmektedir. Radon (1917) tarafından tomografinin temelleri atılmış olup, matematiksel olarak bir boyutlu doğrusal integralleri (projeksiyonları) bilinen bir objenin iki boyutlu görüntüsünün oluşturulabildiğini göstermiştir. Genellikle ışın geometrisinin ve veri dağııımının çok iyi olduğu medikal amaçlı araştırmalarda (Cormack 1963, 1964; Hounsfield 1972a,b) en iyi sonuçları veren tomografi, ilerleyen yıllarda farkı kullanım alanları da bulmuştur (Bracewell, 1956; DeRosier ve Klug, 1968; Lauterbur, 1973). 
Tomografinin yerbilimleri problemlerine uygulanışı ilk olarak, sismik dalgaların ilk varış zamanlarını kullanarak karşılıklı iki kuyu arasındaki hız alanını görüntüleyen Bois vd. (1972) tarafından gerçekleştirilmiştir. Tomografi yöntemi, günümüze değin, farklı veri türleriyle (kırılma, yansıma vb.) araştırma imkânı tanıdığı için lokal ve global ölçekte yerbilimlerinin birçok alanında uygulama imkânı bulmuştur (Aki ve Lee 1976; Dziewonski vd. 1977; Dines ve Lytle 1979; Mason 1981; Anderson ve Dziewonski 1984; Worthington 1984; Bishop vd. 1985; Carrion vd. 1993; Hobro, Singh ve Minshull 2003; Operto vd. 2004; Battaglia vd. 2008; Zhang vd. 2009; Vesnaver vd. 2010). Tomografinin farklı alanlarda kullanılmasının bir sonucu olarak farklı türleri mevcuttur. Bu yöntemleri temelde ışın esaslı ve dalga formu esaslı olmak üzere ikiye ayırmak mümkündür. Bu çalışma kapsamında ışın esaslı yöntemlerden biri olan yansıma tomografisi yöntemi kullanılacaktır. Bu yöntemle sismik dalgaların seyahat zamanları kullanılarak ve yinelemeli ters çözüm yaparak ortama ait doğru hız dağılımının kestirilmesi ve en sığdaki ara yüzeylerden başlayarak en derindeki ara yüzeylere kadar en gerçekçi derinlik-hız modelleri üretilebilmektedir. Ayrıca hız dağılımının yanı sıra soğurulma ve porozite (Accaino vd., 2005) gibi farklı parametreleri de hesaplamak mümkündür.

\section{Seyahat Zamanlarının İşaretlenmesi}

Tomografi yönteminde kullanılan temel veri, sismik dalgaların seyahat zamanlarıdır. Seyahat zamanları, sismik kesitlerin stratigrafik yorumları sonucunda elde edilen seviyeler boyunca sayısallaştırılır. Bu yansıma seviyeleri, yeraltı tabaka sınırlarından yansıyıp gelen, izden ize takip edilebilen ve birbiri ile tutarlı desenlerdir (Bording vd., 1987).

\section{Işın İzleme}

Ortamdaki hız dağılımını bulabilmek için seyahat zamanlarının yanı sıra, bir ışın tarafından seyahat edilen mesafenin de bilinmesi gerekir. Bu nedenle ortamdaki enerji yayılımı, ışın izleme yöntemi ile modellenerek sentetik seyahat zamanları ve ışınların seyahat yolları hesaplanır. Çalışma kapsamında kullanılan CAT3D yazılımında, bir kaynak ve alıcı arasındaki ışın yolunu hesaplamak için minimum zamanlı ışın izleme yöntemi (Böhm vd., 1999) kullanılmaktadır. 


\section{Tomografik Ters Çözüm}

Seyahat zamanlarının ters çözümü, ışın izleme ile elde edilen ışınların geçtiği alanlardaki lokal sismik hızları kestirmemizi sağlar. ART ve SIRT algoritmalarından biri seyahat zamanlarının ters çözümü için kullanılabilmektedir. Bu yöntemlerden ART ve SIRT, düşük hesaplama süresi ve her türlü kaynak-alıcı düzenine uyum sağlaması bakımından uygulamada daha çok tercih edilmektedir. Bu yöntemlerden SIRT yöntemi ise içlerinde en kararlı sonuçları üretmektedir (Lehmann, 2007). Bu yöntem, kestirilen tüm seyahat zamanı hatalarından kaynaklanan düzeltmelerin, yeni bir tahmini hız alanına ulaşmak için aynı anda yapıldığı, yinelemeli bir yeniden yapılandırma algoritmasıdır. İşlem sonuca tatmin edici bir yakınlaşma sağlanana kadar tekrarlı bir şekilde devam ederek hız alanına ulaşır.

İşaretlenen seyahat zamanlarının ters çözümü, ardından da en sığdan en derine doğru ara yüzeylerin konumlarının belirlenmesi 'tabaka sıyırma yaklaşımı (Layer Stripping Approach, Bube ve Burridge, 1983)' esasına göre kestirilir. Tomografik veri-işlem sırasında tabakaların ve ara yüzeylerin ters çözümü ayrı ayrı yapılır. Her bir seviye için, homojen ve sabit hızları olan tabakalar ile yatay olarak tanımlanan ara yüzeylerden başlanarak yinelemeli bir akış izlenir. Her yinelemede, önce seyahat zamanları ters çözüm işlemine sokularak hız alanı güncellenir daha sonra ara yüzeylerin derinlik ve şeklini tahmin etmek için minimum dispersiyon algoritması kullanılır. Hız alanı, seyahat zamanı rezidüelleri minimum olana kadar SIRT algoritması kullanılarak güncellenir. Her bir yinelemede belirlenen bu hız, verilen ara yüzeyden geri yansıyan tüm olaylar için seyahat zamanı rezidüellerini derinliğe dönüştürmede kullanılır (Carrion vd., 1993). Bu elde edilen derinlik değerleri kullanılarak ara yüzeylerin yeni konumları belirlenir.

\section{ÖN VERI - IŞLEM ADIMLARI}

Sismik veriler Şekil 2'de verilen akış diyagramına göre veri-işlem aşamalarından geçirilmiştir. Seyahat zamanı tomografi yöntemi ham atış verileri üzerinde seyahat zamanının işaretlenmesiyle başlar. Ham atış verileri üzerinden tomografik veri işleme başlamadan önce bazı ön veri-işlem aşamalarına ihtiyaç duyulmuştur. Bu aşamalardan ilki, ham atış verilerinde işaretlenecek yansıma seviyelerinin öncelikle sismik yansıma göç kesitlerinde yorumlanarak tespit edilmesidir. Diğer aşama ise ham atış verilerinde var olan ve veriden veriye değişen gürültülerin elimine edilerek, S/G oranını iyileştirmeyi amaçlayan 
ön veri-işlem adımları uygulanmıştır. Böylelikle yansıma hiperbollerinin izden ize takibi ve sığdan derine doğru atış verilerinde seçilebilirliğin arttırılması hedeflenmiştir.

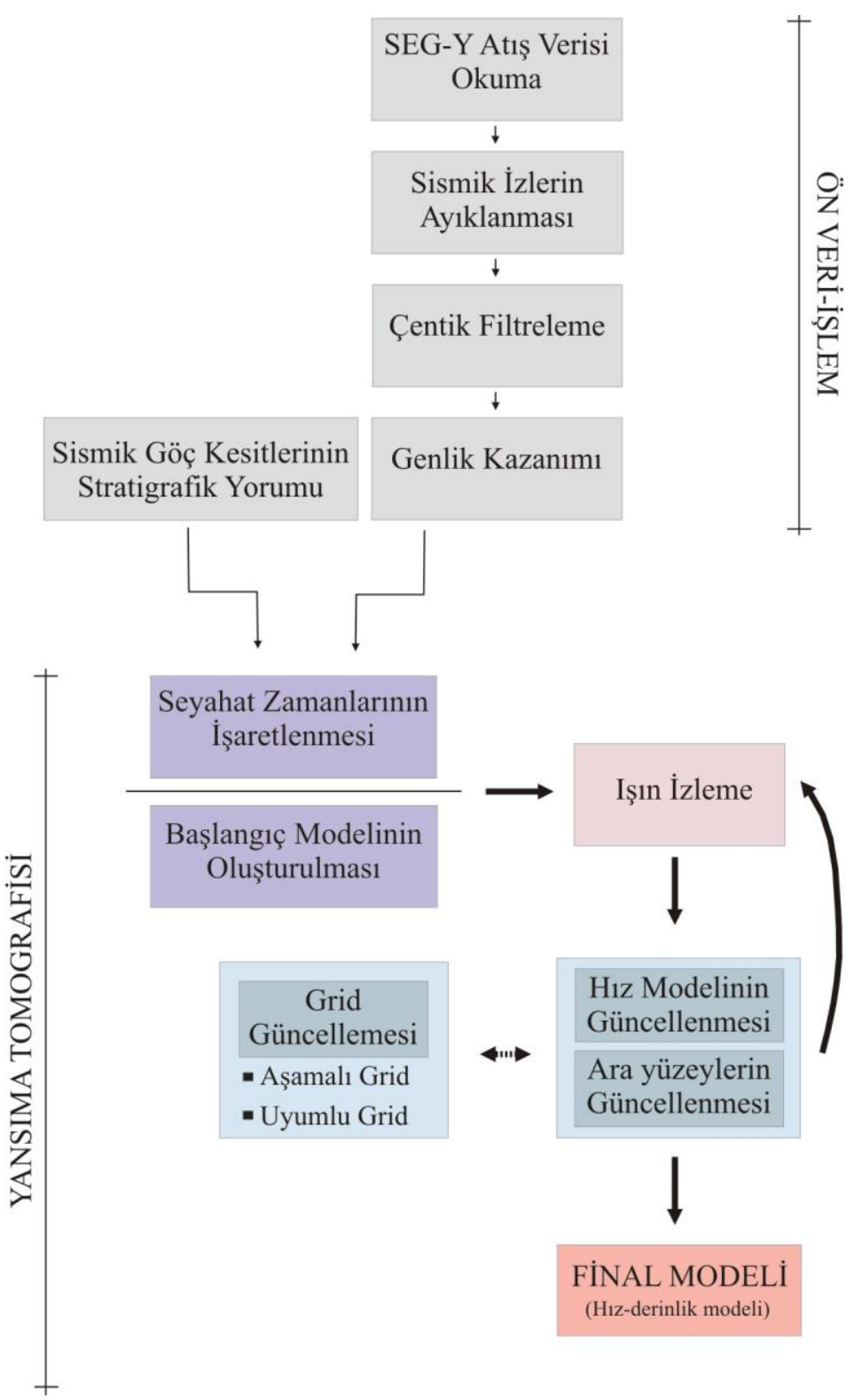

Şekil 2 . Yansıyan varışlar için seyahat zamanı tomografi yöntemi akış şeması.

Figure 2. Scheme of the travel time tomography procedure for the reflected arrivals.

\section{Zaman Ortamı Sismik Yansıma Kesitlerinin Yorumlanması}

Bu aşamada, İzmir Körfezi Foça açıklarında toplanmış ve işlenmiş olan zaman ortamı sismik göç kesiti (Ocakoğlu, 2004), stratigrafik olarak yeniden yorumlanmıştır. Bu 
yorumlamada havza sırt geometrisini oluşturan akustik temelin üst uyumsuzluk yüzeyi H5 ile, havzayı dolduran çökel paketleri ise, yer yer uyumsuzluk yüzeyleri veya yer yer takip edilebilen kuvvetli yansıma yüzeyleri ile H4, H3 ve H2 olarak isimlendirilmiştir. Deniz tabanı yansıma seviyesi ise $\mathrm{H} 1$ olarak işaretlenmiştir. Sismik stratigrafik yorumlama, sahada profil boyunca dört farklı ara yüzeyin $(\mathrm{H} 2-\mathrm{H} 5)$, dört farklı çökel paketi (U1-U4) birbirinden ayırdığını göstermiştir (Şekil 3).

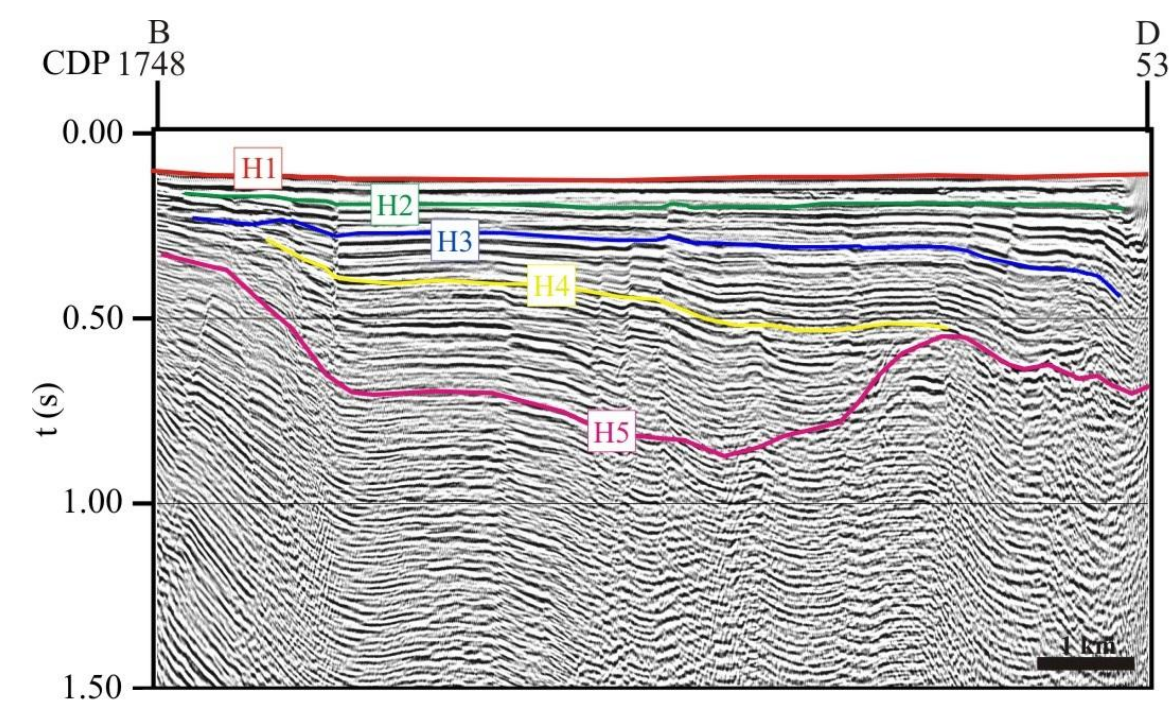

Şekil 3. Zaman ortamı sismik göç kesitinin stratigrafik olarak yorumlanması (Ocakoğlu, 2004'den değiştirilerek).

Figure 3. The stratigraphic interpretation of time migrated seismic section (After Ocakoğlu, 2004).

\section{Sismik Yansıma Verilerinin Gürültülerden Arındırılması}

Ham atış verilerinde gürültülerin bastırılması için öncelikle gürültülü izler ayıklanmıştır. Tüm sismik izler boyunca baskın olan ve sinyali maskeleyen 14 ve $15 \mathrm{~Hz}$ frekansına sahip gürültüler çentik filtreleme yapılarak veriden atılmıştır. Dalganın küresel yayılımından kaynaklanan, artan seyahat zamanıyla genliklerde oluşan kayıpları gidermek için ise, üstel bir fonksiyon ile tüm izlerdeki genlikler ölçeklenmiştir. Tüm bu işlemler verinin S/G oranını artırıp, işaretlenebilirliğini kolaylaştırırken, verinin sahip olduğu seyahat zamanlarına herhangi bir etki söz konusu olmamıştır (Şekil 4). 


\section{YANSIMA SEYAHAT ZAMANI TOMOGRAFISI UYGULAMASI}

İmir Körfezi Foça açıklarındaki çok kanallı sismik yansıma verilerine, Şekil 2'de verilen veri-işlem akış şemasına uygun olarak, yansıma seyahat zamanı tomografisi yöntemi uygulanmıştır. Yansıma seyahat zamanı tomografisi yönteminin uygulanması için sismik yansıma kesitinde yorumlanan $(\mathrm{H} 1-\mathrm{H} 5)$ yansıma seviyeleri, ortak iz kesitlerine taşınmış, daha sonra ilgili seviyelerle ilişkili hiperboller, gürültülerden arındırılmış ortak atış kesitlerinde izden ize takip edilerek seyahat zamanlarının işaretlemesi yapılmıştır.
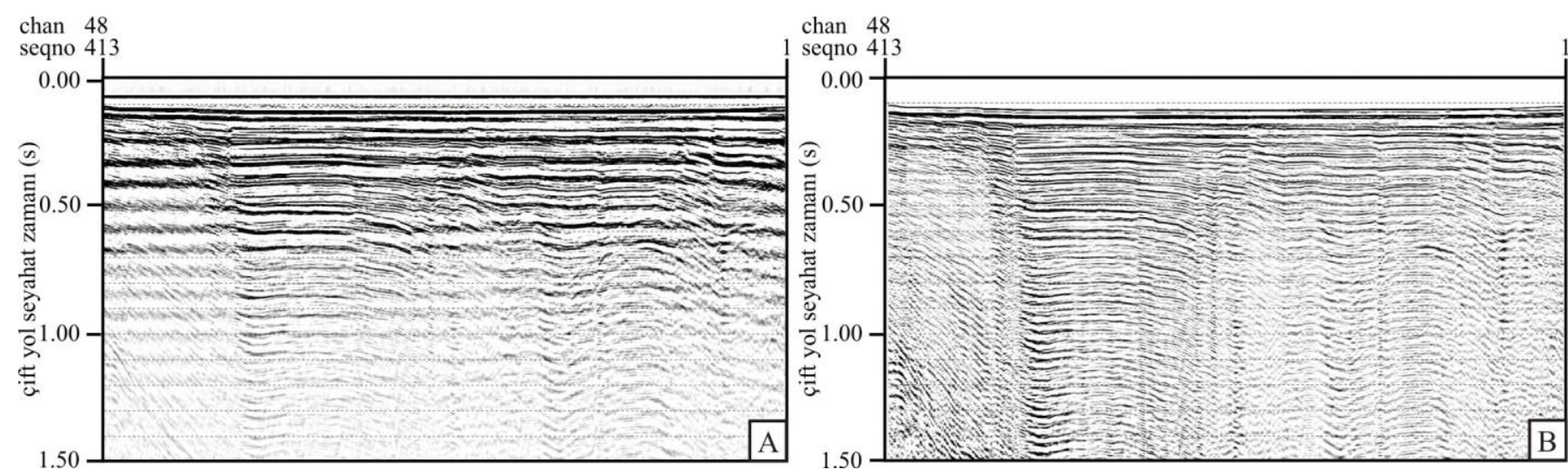

Şekil 4. Ham atış verilerine gürültülerin bastırıması için ön veri-işlem adımlarının uygulanmasından A) önce ve B) sonra sismik veri.

Figure 4. (A) Before and (B) after applying pre-processing to supress noisy signals from raw shot gathers.

Tomografinin başlangıç aşamasında, ortak atış kesitlerinde toplamda 2065 seyahat zamanı işaretlenmiştir. Çalışma alanının yansıma tomografisi, beş ara yüzey ile ayrılan toplamda 130 adet hesaplama hücresi kullanılarak gerçekleştirilmiştir. Her bir hesaplama hücresi, sismik hattın yaklaşık olarak 460 m'lik uzunluğunu temsil etmektedir. En sığda bulunan deniz tabanını temsil eden $\mathrm{H} 1$ seviyesinden başlanarak kaynak-alıcı geometrisi tanımlanmıştır. Şekil 5a'da gösterilen H1 seviyesine ait kaynak-alıcı geometrisinde sismik verilerin toplanma düzeninden kaynaklanan, verinin olmadığı bazı alanlar (gri renkli alanlar) bulunmaktadır. Tomografik çözümün güvenirliliğini ve çözünürlüğünü düşürmemek için herhangi bir bilginin olmadığı bu alanların etkisi veriden çıkarılmıştır. Böylelikle grid hücrelerinin, ışın yolu geometrisine göre daha iyi dağılımı sağlanmıştır (Şekil 5b). 

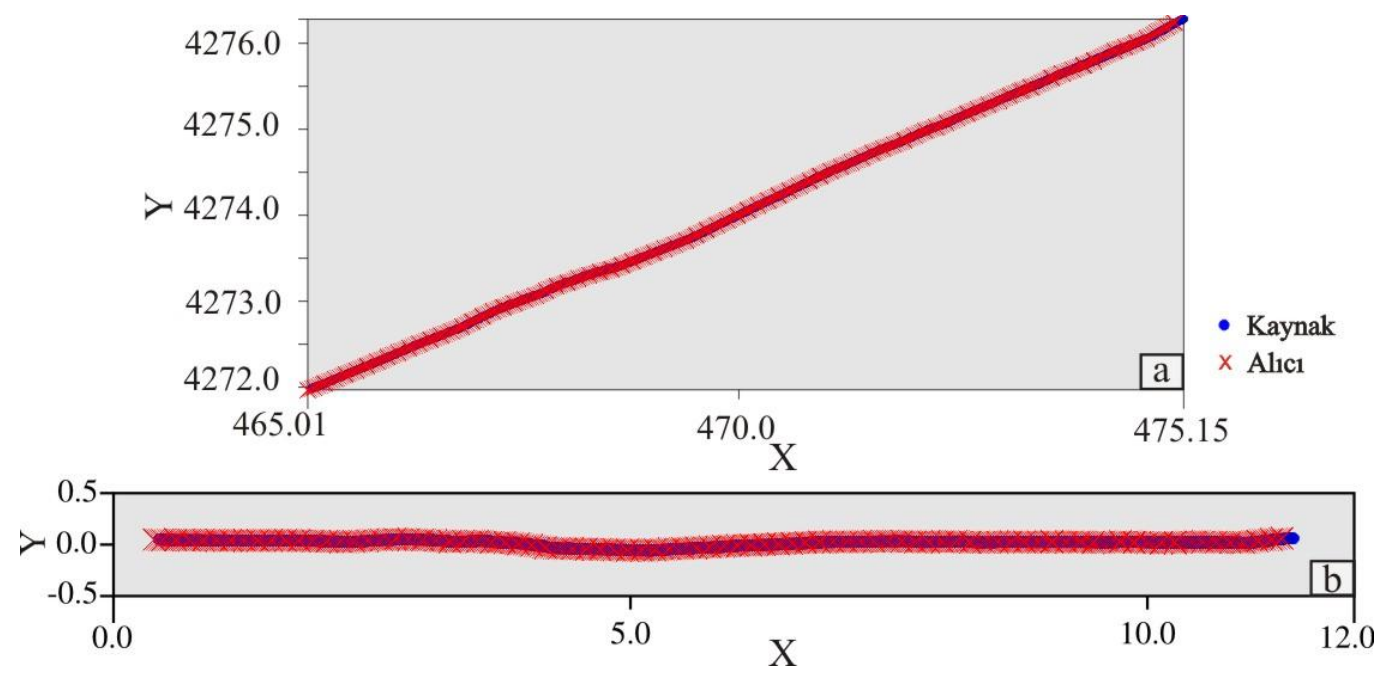

Şekil 5. Sismik hatta uygulanan koordinat rotasyonu; a. Hattın orijinal pozisyonu, b. Döndürülmüş geometri.

Figure 5. Coordinate rotation applied to seismic line; a. Original position, b. Rotated geometry.

Başlangıç modeli için, homojen ve sabit $1.5 \mathrm{~km} / \mathrm{s} \mathrm{P}$ dalga hızına sahip bir tabaka ile yaklaşık olarak $0.1 \mathrm{~km}$ derinlikte yatay bir ara yüzey tanımlanmıştır (Şekil 6). Seçilen 2B sismik hattın uzunluğu yaklaşık 12 km'dir. Su kolonunu temsil eden ilk tabaka 13x1 grid hücresine sahip dörtgen şekilli düzenli hücreler kullanılarak ayrıklaştırılmıştır.

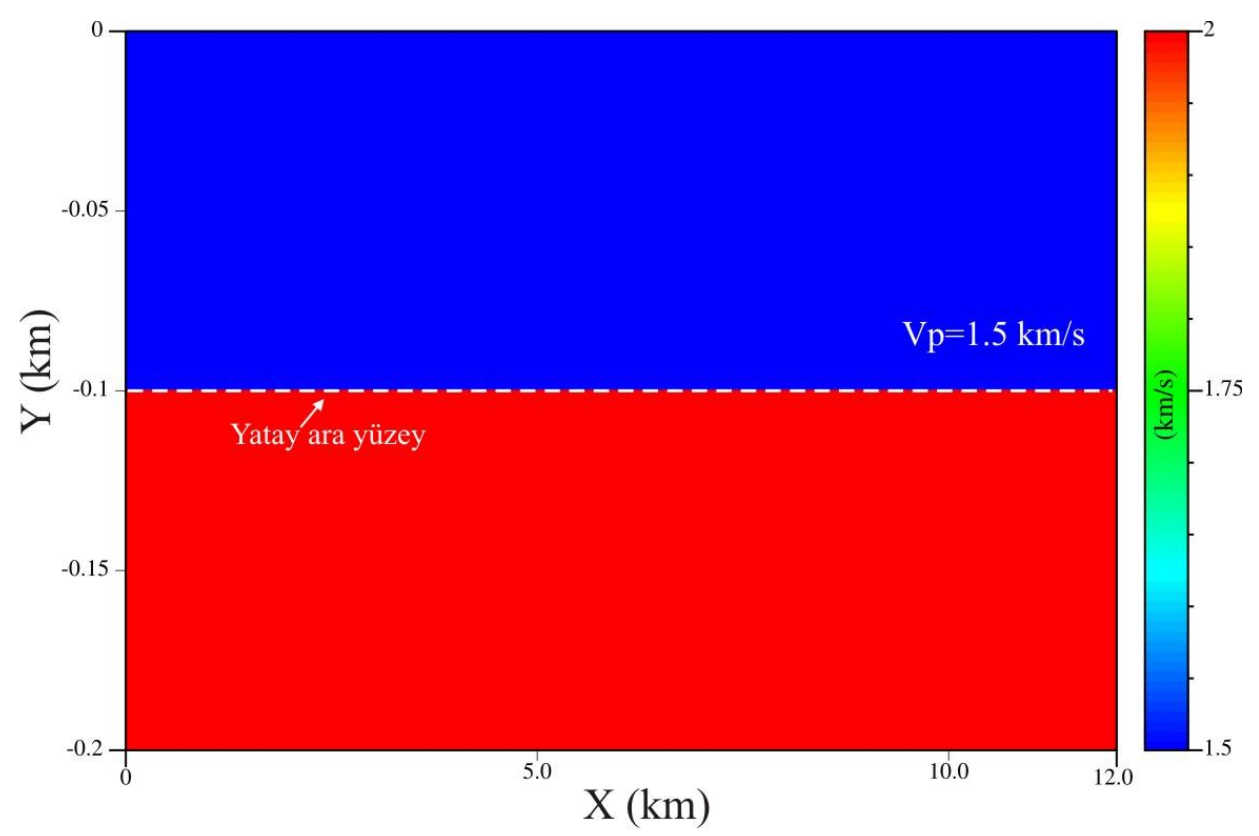

Şekil 6. Tomografik ters-çözümde kullanılacak olan başlangıç modeli.

Figure 6. Initial model for tomografic inversion. 
Belirlenen başlangıç modeli, ışın yollarının izlenmesinde kullanılır. Bu aşamada ters çözüm için kullanılan SIRT yöntemi ile, ilgili yinelemedeki ışın izleme ile elde edilen yansıma noktalarındaki lokal hızlar hesaplanır. Her bir yinelemedeki seyahat zamanı rezidülleri, lokal hızlar kullanılarak derinliğe dönüştürülür. Hesaplanan bu derinlik değerleri, her bir yansıma noktasının düşey koordinatına eklenerek, ters çözümü yapılan ara yüzeyin güncel konumu belirlenir. Daha sonra bu model kullanılarak yeni bir ışın izleme seyahat zamanı ters çözümü gerçekleştirilir. Böylece, her bir yinelemede bir önceki yinelemeye göre hem hız alanının hem de ara yüzeyin iyileştirildiği yeni bir model elde edilir (Şekil 7).

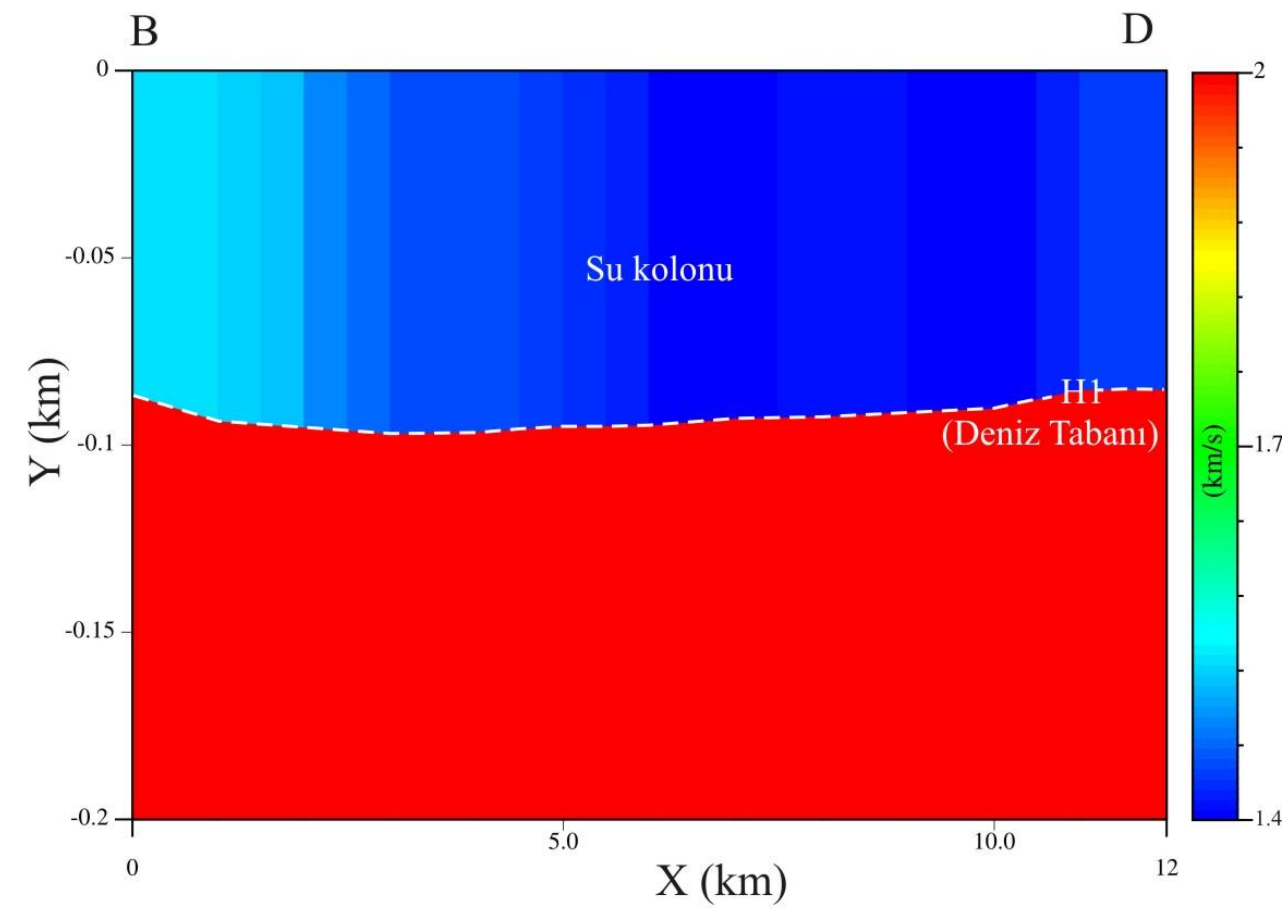

Şekil 7. 15 yineleme sonunda su kolonu için elde edilen hız tomogramı (kırmızı ile gösterilen tabaka için ters çözüm yapılmamıştır).

Figure 7. Velocity tomogram for water column after 15 iterations (the layer represented by red color is not inverted).

Seyahat zamanı rezidüelleri minimum olana kadar ters çözümü yapılan tabakanın hız dağılımı ve ara yüzey konumu güncellenir. Ulaşılan son yinelemede bu tabakaya ait ara hız değerlerinin 1.4 km/s ile 1.54 km/s arasında değiştiği görülmüştür. Yanal yönde değişen bu hız dağılımı kullanılarak deniz tabanını temsil eden $\mathrm{H} 1$ ara yüzeyinden yansıyan tüm yansıma noktalarının konumları güncellenmiştir (Şekil 8). 
Daha sonra, elde edilen çözümün gerçek modele yeterince yakınsayıp yakınsamadığını kontrol etmek için seyahat zamanı rezidüellerine bakılmıştır. Şekil 9a'da tüm kaynak-alıcı çiftleriyle ilişkili seyahat zamanı rezidüel haritası gösterilmektedir. Renk skalasında kırmızı renk pozitif rezidüel değerlerini, yeşil renk ise negatif rezidüel değerlerini göstermektedir. Şekil 9b'de ise tüm kaynak-alıcı çiftleri arasından örnek olarak seçilen 85. atışa ait zaman

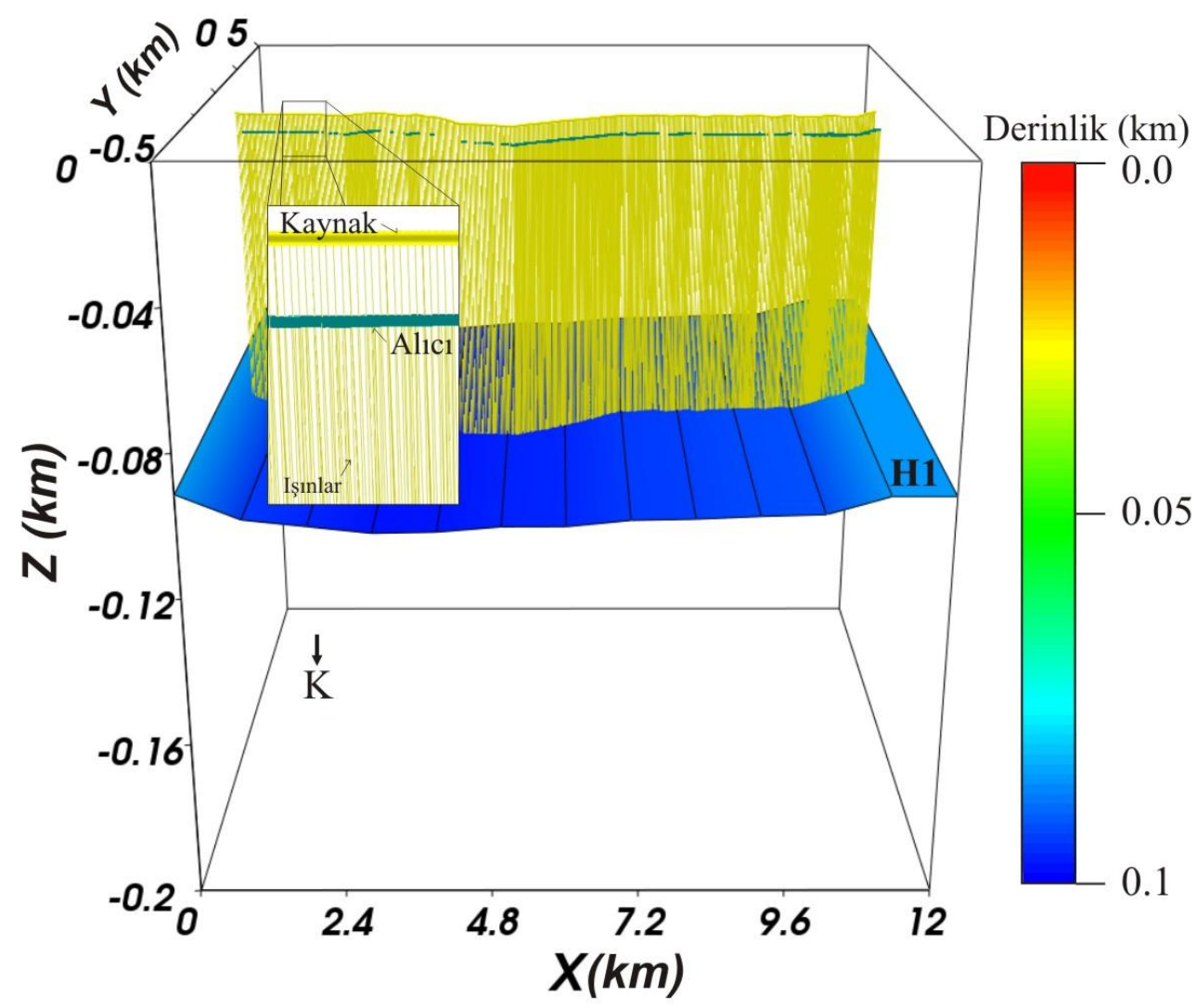

Şekil 8. H1 ara yüzeyinin güncel konumu ve yansıyan olaylarla ilişkili ışın yolları.

Figure 8 . Shape and depth of $\mathrm{H1}$ interface and ray paths associated to the reflected events.

rezidüelleri görülmektedir. Bu grafikte, yakın ofsete ait izlerde işaretlenen ve hesaplanan zaman değerleri arasında fark gözlenmezken; sadece çok uzak ofsetlerde \%5'in altında bir fark görülmektedir. Şekil 9c'de, yüzde olarak rezidüel dağılımının Gauss tipi olduğu görülmektedir. Şekil 9d'de ise veri kalitesi hakkında fikir veren bazı istatiksel parametrelerin, her bir ara yüzey güncellemesindeki değişimi verilmektedir. Şekil 9e'de tabakaların hız dağılımları hesaplanırken gerçekleştirilen yinelemelerden seçilen 10. yinelemede istatiksel parametrelerin değişimi gösterilmektedir. 
H1 ara yüzeyi ve üzerindeki tabakaya ait hız dağılımı için gerçekleştirilen tomografik ters çözümün güvenirliliği kontrol edildikten sonra; H2, H3, H4 ve H5 ara yüzeylerinin güncel konumlarını bulmak ve bu ara yüzeylerin arasında kalan çökel birimlerin hız dağılımlarını

hesaplamak için yukarıda sözü edilen tabaka sıyırma yaklaşımı uygulanmıştır. Bu yaklaşım gereği, elde edilen model bir sonraki tabaka ve ara yüzeyin tomografik ters çözümünde başlangıç modeli olarak kullanılır. H2 ara yüzeyi ve bu ara yüzeyin üzerinde kalan çökel birimin yansıma tomografisi için Şekil 7'de gösterilen, $\mathrm{H} 1$ ara yüzeyi ve üzerindeki su kolonu için elde edilmiş hız modeli, başlangıç modeli olarak kullanılmıştır. Su kolonu altında kalan tüm tabakaların ters çözümleri sırasında hız kısıtlayıcı tanımlanması gerekmektedir. Bunun için Ocakoğlu (2004) tarafından rutin veri işlem sırasında elde edilen Karekök Ortalama Hızlarından (RMS-Root Mean Square Velocities) faydalanılmıştır. Şekil 2'de gösterilen yansıma tomografisi akış şemasında belirtilen adımlar sırasıyla her bir tabaka için uygulanarak, deniz tabanı ve akustik temel arasında kalan çökel birimlerin hız dağılımları ve H2, H3, H4 ve H5 ara yüzeylerinin derinlik ortamındaki değişimleri elde edilmiştir.

\section{SONUÇLAR}

Bu çalışmada, yansıma tomografisi yöntemi ile, İzmir Körfezi Foça-Karaburun açıklarının sismik stratigrafik özellikleri ve hız yapısı detaylı olarak araştırılmış ve yaklaşık olarak $1 \mathrm{~km}$ derinliklere kadar ara yüzey derinlikleri ilk kez ortaya çıkarılmıştır.

Foça-Karaburun açıklarında BGB-DKD uzanımlı yaklaşık 12 km uzunluğundaki çok kanallı sismik yansıma profili sismik stratigrafik olarak yorumlanmıştır. Yorumlamalar zaman ortamı sismik göç işlemi uygulanmış sismik kesit üzerinde yapılmıştır. Stratigrafik olarak sahada farklı yansıma şekillenmelerine sahip dört farklı yansıma paketi (U1-U4), birbirlerinden dört uyumsuzluk yüzeyi (H2-H5) ile ayrılmıştır (Şekil 3). Yorumlanan bu ara yüzeylere yansıma seyahat zamanı tomografisi yöntemi uygulanarak akustik temel ile deniz tabanı (H1) 
arasında kalan çökel birimlerin detaylı hız-derinlik modeli elde edilmiştir (Şekil 10).
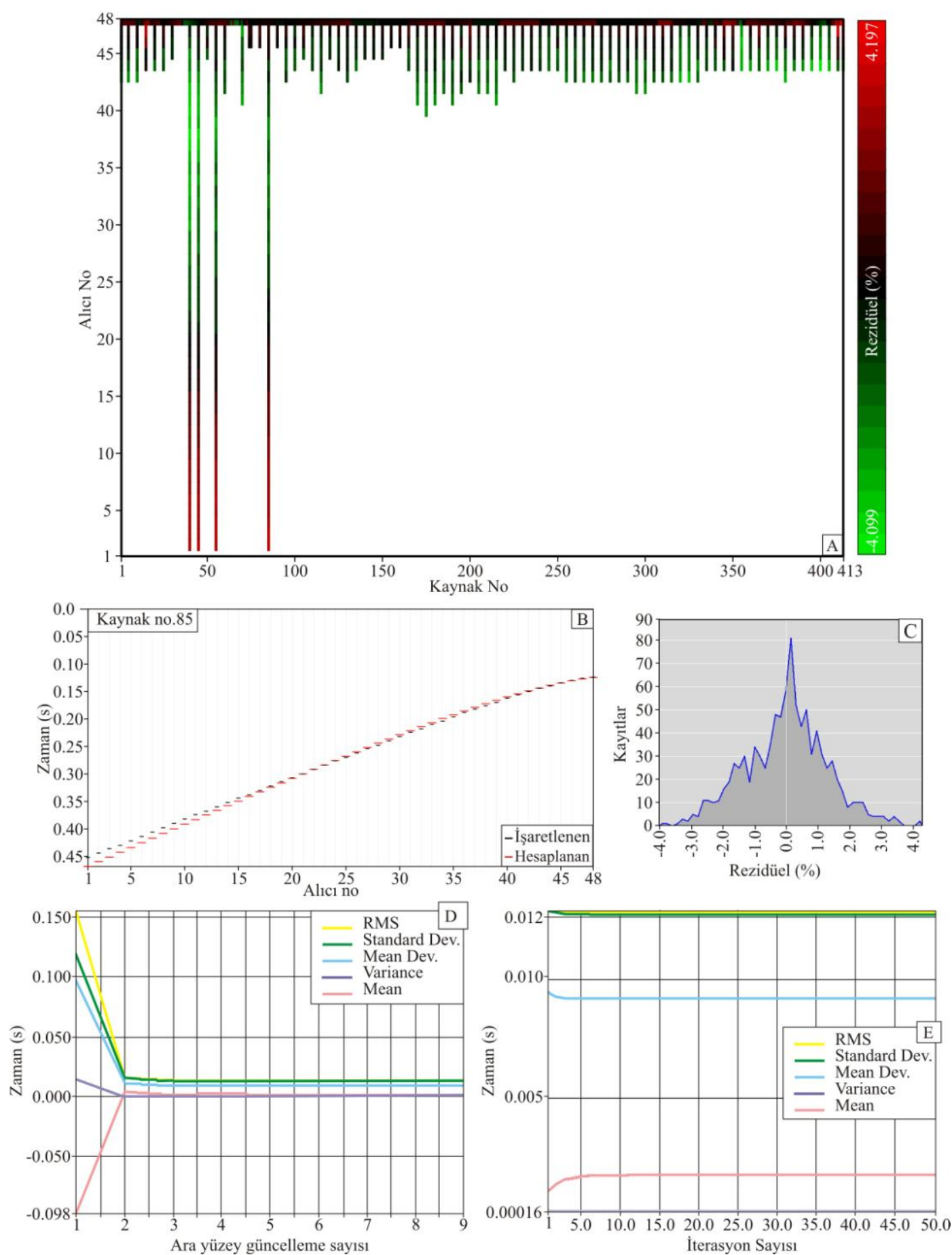

Şekil 9. a) Tüm kaynak-alıcı çiftleriyle ilişkili zaman rezidüellerinin haritası, b) 85 no'lu kaynakla ilişkili zaman rezidülleri, c) Yüzde olarak rezidüel dağılımı d) Veri kalitesi hakkında fikir veren bazı istatiksel parametrelerin, her bir ara yüzey güncellemesindeki değişimi e) Tabaka hız dağılımı için gerçekleştirilen 10. yinelemede istatiksel parametrelerin değişimi.

Figure 9. a) Map of the time residuals associated to all the source-receiver couples, b) Time residuals associated to a single source, c) Plot of the residual distribution in percentage, d) Statistical parameters set at each interface update, e) Same statistical parameters at the $10^{\text {th }}$ iteration for velocity field update. 
Toplamda 15 yineleme sonucunda elde edilen hız tomogramı detaylı incelendiğinde, deniz tabanı üzerinde bulunan su kolonunun P dalgası ara hız değerinin $1.4-1.53 \mathrm{~km} / \mathrm{s}$ arasında değiştiği görülmüştür. Deniz tabanı ile H2 ara yüzeyinin arasında kalan çok ince bir çökel istife sahip U1 biriminin hızı ise $1.5-1.58 \mathrm{~km} / \mathrm{s}$ arasında değişmektedir. Bu birimin hemen altında bulunan U2 istifi, $1.6-1.96 \mathrm{~km} / \mathrm{s}$ arasında değişen hızlara sahiptir. H3 ve H4 ara yüzeyleri, ara hız değerleri 1.89-2.07 km/s aralığında değişmekte olan U3 çökel birimini sınırlamaktadırlar. Son olarak akustik temelin üzerinde, H4 ve H5 seviyeleri arasında kalan U4 biriminin ise 1.8-2.7 km/s arasında değişen ara hızlara sahip olduğu görülmüştür. Sismik profil boyunca $3.5 \mathrm{~km}, 8 \mathrm{~km}$ ve $11 \mathrm{~km}$ uzaklıkta alınan düşey 1B hız fonksiyonlarında yanal yöndeki ara hız değişimi görülmektedir (Şekil 10b-10d). Ara hızlar, deniz tabanından itibaren akustik temele kadar derinlikle artmaktadır.

Yansıma tomografisi sonucu her bir yinelemede elde edilen hız dağılımları kullanılarak ara yüzeylerin derinlik ekseninde konumları ve üst yüzey morfolojileri güncellenmiştir. Şekil 11'da elde edilen final yeraltı modelinde ara yüzeylerin derinlik değişimleri gösterilmektedir. Bu ara yüzeylerden en sığda yer alan ve deniz tabanını temsil eden H1 seviyesi, görece düz bir deniz tabanı morfolojisi ortaya koyarak, profil boyunca batıdan doğuya doğru yaklaşık 90 m'den 97 m'ye derinleşmektedir. Tabanın hemen altındaki iki farklı çökel istifi birbirinden ayıran $\mathrm{H} 2$ ara yüzey morfolojisi, deniz tabanıyla benzerlik göstermektedir. Bu ara yüzey hattın batısında yaklaşık olarak 125 m derinliklerde iken; doğuya doğru yaklaşık 155 m derinliğe ulaşmaktadır. Değişen bu derinlik değerleri $\mathrm{H} 1-\mathrm{H} 2$ ara yüzeyleri arasındaki çökel istifin göreceli olarak doğuya doğru kalınlaştığını göstermektedir. H3 ara yüzeyi ise H1 ve $\mathrm{H} 2$ ara yüzeylerine göre ondülasyonlu bir morfolojiye sahiptir. Bu uyumsuzluk yüzeyi hattın batısında 184 m derinlikte iken doğuya doğru 335 m derinliklere ulaşmaktadır. 

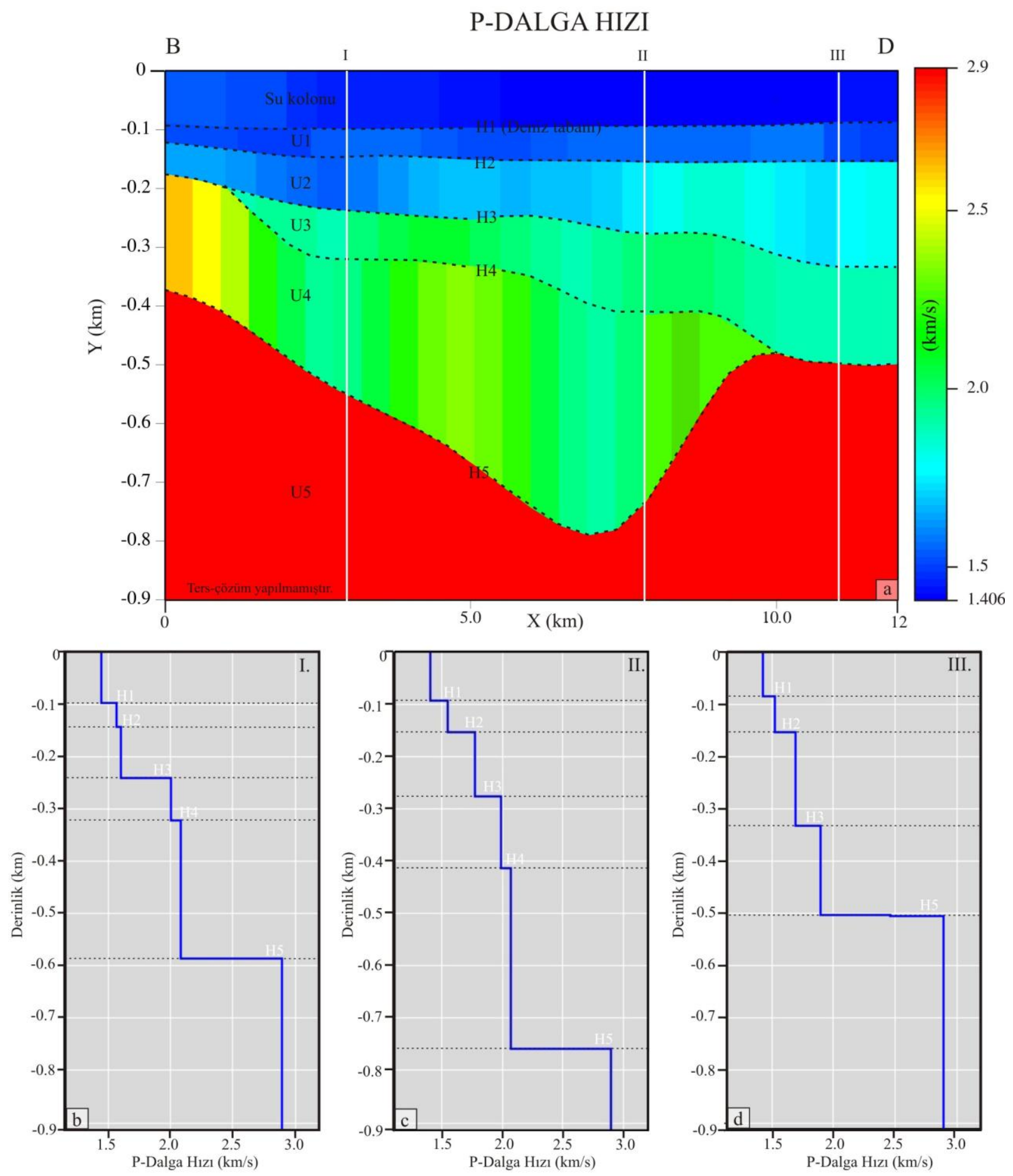

Şekil 10. a) Sismik yansıma profiline uygulanan yansıma tomografisi sonucu elde edilen hız tomogramı (kırmızı ile gösterilen tabaka için ters çözüm yapılmamıştır), b) $X=3.5$ km'de alınan $1 B$ düşey $P$ dalgası hız fonksiyonu, c) $X=8$ km'de alınan $1 B$ düşey $P$ dalgası hız fonksiyonu, d) $X=11$ km'de alınan 1B düşey $P$ dalgası hız fonksiyonu.

Figure 10. a) Velocity tomogram of the seismic line by reflection tomography (the layer represented by red color is not inverted), b) $1 D$ vertical velocity function at $X=3.5 \mathrm{~km}, c) 1 D$ vertical velocity function at $X=8 \mathrm{~km}, d)$ $1 D$ vertical velocity function at $X=11 \mathrm{~km}$.

$\mathrm{Bu}$ durum H2-H3 arasında kalan çökel birimin batıdan doğuya doğru kalınlaştığını göstermektedir. Bu çökel istif batıda $\mathrm{H} 4$ ara yüzeyine yaslanarak sonlanmaktadır. H4 
uyumsuzluk yüzeyi; H3 ara yüzeyine benzer şekilde ondülasyonlu bir morfolojiye sahip olup doğuya doğru derinleşerek yaklaşık 400 m' lerde H5 ara yüzeyine yaslanarak sonlanmaktadır. Bu durum H3-H4 arasındaki çökelen birimin de üzerindeki diğer birimler gibi doğuya doğru göreceli olarak kalınlaştığını göstermektedir. Çalışma sahasında en derinde bulunan akustik temelin üst yüzey morfolojisi ise $(\mathrm{H} 5)$ geometrik olarak sahada en fazla değişim gösteren uyumsuzluk yüzeyidir. H5 ara yüzeyi batıdan doğuya doğru derinleşerek bir havza geometrisi oluşturmakta; daha sonra aniden sığlaşarak en doğuda bir sırt yapısının varığını ortaya koymaktadır. Havzanın batıda derinleştiği kısmına doğru tomografik sonuçlar 340 metre derinlikleri gösterirken, havzanın en derin olduğu orta kısmında derinlik 800 metreye ulaşmaktadır. Doğuya doğru havzayı takip eden sırt yapısı ise sığlaşarak yaklaşık 400 metre derinliktedir. Bu sonuçlar ile İzmir Körfezi içerisinde Karaburun-Foça arasında yaklaşık GB-KD uzanımlı, batıdan doğuya derinleşen bir havza geometrisi ve bu havzayı dolduran çökel istifin hız-derinlik modeli detaylı olarak ortaya konmuştur.

\section{KATKI BELIRTME}

Bu araştırma İstanbul Teknik Üniversitesi Bilimsel Araştırma Projeleri Koordinasyon Birimi (Proje no: 39685) desteğiyle gerçekleştirilmiştir. Sismik veriler 2000 yılında TÜBiTAK 100Y084 no.lu Araştırma Projesi kapsamında ve TÜBITAK-ITTÜ-MTA ortaklığında, MTA kurumu tarafından toplanmıştır. Yazarlar verilerin toplanmasındaki katkılarından dolayı proje yürütücüsüne ve ilgili kurumların koordinatörlerine teşekkür ederler. Çalışma kapsamında CAT3D yazılımının kullanılmasına izin verdiği için İtalya, "Istituto Nazionale di Oceanografia e di Geofisica Sperimentale (OGS)" kurumuna teşekkür ederler. Ayrıca yazarlar makalenin gelişmesindeki katkılarından dolayı dergi editörlerine ve hakemlerine teşekkür ederler. Çalışma kapsamında gösterilen haritalardan bazıları Qgis 3.2 Bonn açık kaynaklı yazılımı kullanılarak hazırlanmıştır. 


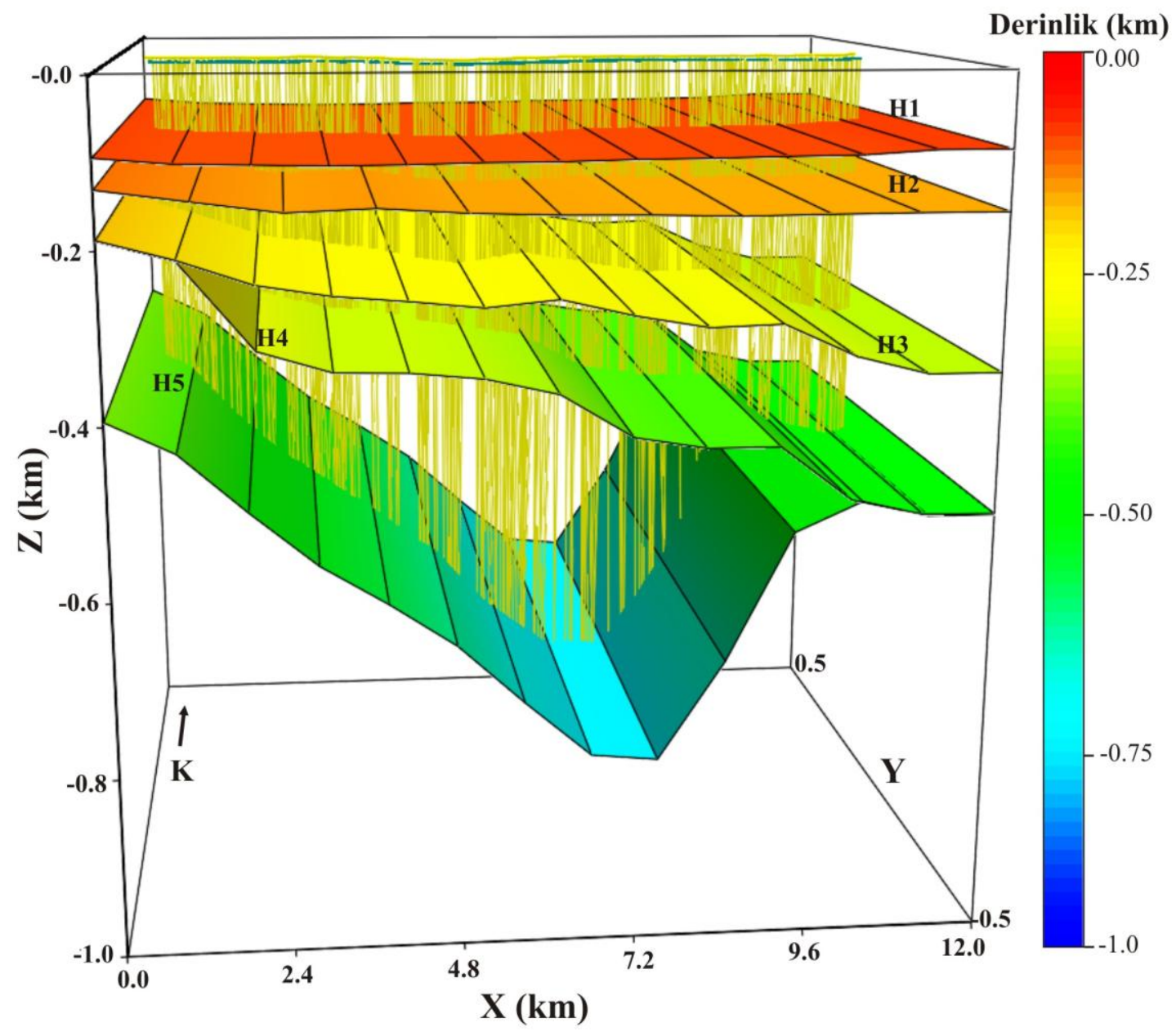

Şekil 11. Yorumlanan beş ara yüzeyin yansıma tomografisi sonucunda elde edilen şekil ve derinlikleri ile bu derinliklerin güncellenmesinde kullanılan yansıyan olaylarla ilişkili ışın yolları.

Figure 11. Ray paths associated with the reflected events used for the updating the depths and the shapes of the interpreted five horizons by reflection tomography.

\section{KAYNAKLAR}

Accaino, F., Böhm, G., Brancolini, G., 2005. Analysis of Antarctic glaciations by seismic reflection and refraction tomography. Marine Geology, 216, 145-154.

Aki, K., Lee, W.H.K., 1976. Determination of three-dimensional velocity anomalies under a seismic array using $P$ arrival times from local earthquakes: 1.A homogeneous initial model. J. Geophys.Res., 81, 4381-4399,123.

Altan, Z., Ocakoğlu, N., 2016. Shallow seismic study of the geothermal areas in the Gülbahçe Bay and İzmir Gulf (Aegean Sea, Western Turkey). Mar. Geop. Research, 37 (4), 297-311.

Anderson, D.L., Dziewonski, A.M., 1984. Seismic tomography. Scientific American, 251, 60 68. 
Battaglia, J., Zollo,A., Virieux, J., Dello lacono, D., 2008. Merging active and passive data sets in traveltime tomography: the case study of Campi Flegrei caldera (Southern Italy). Geophys. Pros., 56, 555-573.

Bishop, T.N., Bube, K.P., Cutler, R.T., Langan, R.T., Love, P.L., Resnick, J.R., Shuey, R.T., Spindler, D.A., Wyld, H.W., 1985. Tomographic determination of velocity and depth in laterally varying media. Geophysics, 50, 903-923.

Bois, P., LaPorte, M., LaVergne, M., Thomas, G., 1972. Well-to-well seismic measurements. Geophysics, 37, 741-480.

Bording, R.P., Gersztenkorn, A., Lines, L.R., Scales, J.A., Treitel, S.T., 1987. Applications of seismic traveltime tomography. Geophys. J.R. astr. S., 90, 285-303.

Bourbié, T., Coussy, O., Zinszner, B., 1987. Acoustics of porous media. Institut Français du Pétrole Publications, Paris (syf. 240).

Böhm, G., Rossi, G., Vesnaver, A., 1999. Minimum time ray tracing for 3D irregular grids. J. Seism. Explor., 8, 117-131.

Böhm, G., Accaino, F., Rossi, G., Tinivella, U., 2006. Tomographic joint inversion of first arrivals in a real case from Saudi Arabia. Geop. Prospecting, 54, 721-730.

Böhm, G., Ocakoğlu, N., Picaotti, S., De Santis, L., 2009. West Antarctic Ice Sheet evolution: New insights from a seismic tomographic 3D depth model in the Eastern Ross Sea (Antarctica). Marine Geology, 266, 109-128.

Boehm, G., Francese, R., Giorgi, M., 2010. Bedrock detection from an integrated procedure of refraction analysis and tomographic inversion of the first arrivals. The 16th European Meeting of Environmental and Engineering Geophysics of the Near Surface Geoscience Division of EAGE, Zurich, Switzerland, Abstracts, p41.

Bracewell, R.N., 1956. Strip integration in radio astronomy. Australian J. of Physics, 9, 198217.

Bube, K.P. and R. Burridge, 1983. The one-dimensional inverse problem of reflection seismology. SIAM Review, 25, 497-559.

Carrion, P., Boehm, G., Marchetti, A., Pettenati, F. ve Vesnaver, A., 1993a. Reconstruction of lateral gradients from reflection tomography. J. Explor. Seism, 2, 55-67.

Çiftçi, N. B., Temel, R. O. ve Terzioğlu, N. M., 2004. Neogene stratigraphy and hydrocarbon system of the region surrounding the Gulfof Edremit, NW Anatolia, Turkey. Bulletin of Turkish Association of Petroleum Geologists, 16, 81-104.

Cormack, A.M., 1963, Representation of a function by its line integrals with some radiological applications. J. Appl. Phys., 34, 2722-2727. 
Cormack, A.M., 1964. Representation of a function by its line integrals with some radiological applications. II. J. Appl. Phys., 35, 2908-2913.

DeRosier, D.J., Klug, A., 1968. Reconstruction of three dimensional structures from electron micrographs. Nature, 217, 130-134.

Dines, K. A. ve Lytle, R. J., 1979. Computerized geophysical tomography. Proceedings of the IEEE, 67(7): 1065-1073.

Dziewonski, A.M., Hager, B.H., O'Connell, R.J., 1977. Large-scale heterogeneities in the lower mantle. J. Geophysical Res., 82(2), 239-255.

Gilbert, P.F.C., 1972. An iterative method for three-dimensional reconstruction of an object from projections. J. Theor. Biol., 36, 105-117.

Gürgey, K., Simoneit, B. R. T., Bati, Z., Karamanderesi, I. H., ve Varol, B., 2007. Origin of petroliferous bitumen from the Buyuk Menderes-Gediz geothermal graben system, Denizli-Saraykoy, western Turkey. Applied Geochemistry, 22, 1393-1415.

Hobro, J. W. D., Singh, S.C., Minshull, T.A., 2003. Three-Dimensional tomographic inversion of combined reflection and refraction seismic traveltime data. Geophysical Journal International, 152 (7), 79-93.

Hounsfield, G.N., 1972a. A method of and apparatus for examination of a body by radiation such as X-ray or gamma radiation. Patent Specification, 1283915.

Hounsfield, G.N., 1972b. Computerized traverse axial scanning (tomography) Part I: Description of system. British J. Radiology, 46, 1016-1022.

IOC, IHO ve BODC, 2003. "Centenary Edition of the GEBCO Digital Atlas", published on CDROM on behalf of the Intergovernmental Oceanographic Commission and the International Hydrographic Organization as part of the General Bathymetric Chart of the Oceans; British Oceanographic Data Centre, Liverpool.

Kessler, D., Kosloff D., Codd, J., Bartana, A., 2017. Depth Imaging-More than PSDM. The 15th International Congress of the Brazilian Geophysical Society (31 July-3 August), Rio de Janerio, Brazil.

Lauterbur, P.C., 1973. Image formation by induced local interactions: Examples employing nuclear magnetic resonance. Nature, 242, 190-191.

Mason, I.N., 1981. Algebraic Reconstruction of a two-dimensional velocity inhomogeneity in the High Hazles seam of Thoresby Colliery. Geophysics, 46, 298-308.

NASA's Earth Observing System Data and Information System (EOSDIS), Copernicus Sentinel data [2018]. Retrieved from ASF DAAC [1.10.2018], processed by ESA. 
Ocakoğlu, N., 2004. İzmir körfezi ve Alaçatı-Doğanbey-Kuşadası açıkları aktif tektoniğinin sismik yansıma verileri ile incelenmesi. Doktora Tezi, İstanbul Teknik Üniversitesi, İstanbul, Türkiye.

Ocakoğlu, N., Demirbağ, E., Kuşçu, İ., 2005. Neotectonic structures in İzmir Gulf and surrounding regions (western Turkey): Evidences of strike-slip faulting with compression in the Aegean extensional regime. Marine Geology, 219, 155-171.

Operto S., Ravaut C., Improta L., Virieux J., Herrero A. ve Dell'Aversana P., 2004. Quantitative imaging of complex structures from dense wide-aperture seismic data by multiscale traveltime and waveform inversions: a case study. Geophysical Prospecting, 52, 625-651.

QGIS Development Team, 2018. QGIS Geographic Information System. Open Source Geospatial Foundation Project. http://qgis.osgeo.org.

Radon, J., 1917. Über die Bestimmung von Funktionen durch Integralwerte langsgewisser Manigfaltigkeiten. Ber.sachs. Akad der Wiss., 69, 262-277.

Rossi, G., Böhm, G., Madrussani, G., 2011. Tomographic inversion of ocean bottom seismograph (OBS) data: Problems and solutions applied to the NW Svalbard Hydratech data set. Computers \& Geosciences, 37, 1535-1544.

van der Sluis, A and van der Vorst, H. A., 1987. Numerical solution of large, sparse linear algebraic systems arising from tomographic problems. In: Seismic Tomography with applications in global seismology and exploration geophysics (ed G. Nolet). D. Riedel Publishing Co, Dordrecht.

Vesnaver, A., 1996. The contribution of reflected, refracted and transmitted waves to seismic tomography: a tutorial1. First Break, 14 (5), 159-168.

Vesnaver, A., Böhm, G., Madrussani, G., Rossi, G., Granser, H., 2000. Depth imaging and velocity calibration by 3D adaptive tomography. First Break, 18 (7), 303-312.

Vesnaver, A., Lovisa, L., Böhm, G., 2010. Joint 3D processing of active and passive seismic data. Geophys. Prospect., 58, 831-844.

Worthington, M. H., 1984. An introduction to geophysical tomography. First Break, 22, 20 26.

Zhang, H., Sarkar, S., Toksöz, N., Kuleli, H., Al-Kindy, F., 2009. Passive seismic tomography using induced seismicity at a petroleum field in Oman. Geophysics, 74(6), WCB57-WCB69. 